\title{
Assessment of Spring Water Quality in the Rural Watersheds of Western Nepal
}

\author{
Anup Gurung1*, Sanot Adhikari'1, Raju Chauhan1, Sudeep Thakuri ${ }^{1}{ }^{2}$, Selina Nakarmi ${ }^{1}$, \\ Deepak Rijal $^{3}$, Bhawani S. Dongol ${ }^{3}$ \\ ${ }^{1}$ Youth Alliance for Environment, Kathmandu, Nepal \\ ${ }^{2}$ Central Department of Environmental Science, Tribhuvan University, Kathmandu, Nepal \\ ${ }^{3}$ Program for Aquatic Natural Resources Improvement (PANI), USAID, Kathmandu, Nepal \\ Email: ^anuptamu@gmail.com
}

How to cite this paper: Gurung, A., Adhikari, S., Chauhan, R., Thakuri, S., Nakarmi, S., Rijal, D., \& Dongol, B. S. (2019). Assessment of Spring Water Quality in the Rural Watersheds of Western Nepal. Journal of Geoscience and Environment Protection, 7, 39-53.

https://doi.org/10.4236/gep.2019.711004

Received: October 30, 2019

Accepted: November 8, 2019

Published: November 11, 2019

Copyright $\odot 2019$ by author(s) and Scientific Research Publishing Inc. This work is licensed under the Creative Commons Attribution International License (CC BY 4.0).

http://creativecommons.org/licenses/by/4.0/

\begin{abstract}
A preliminary study was conducted to analyze the water quality of spring waters in rural watershed of Western Nepal. 155 spring water samples were collected from Jhimruk, Rangun, Bogtan-Lagam Karnali, Thuligad and Middle Karnali watershed. Collection and analysis occurred twice, once in pre-monsoon 2018 and post-monsoon 2018. Various physical and chemical parameters were analyzed by using standard water quality measurements and compared with the Nepal Drinking Water Quality Standard and the World Health Organization Standard Guideline. The results indicate that the turbidity was high during pre-monsoon season. The highest turbidity of 63.8 NTU was observed in the Bogtan-Lagam Karnali watershed. Two spring sources-one in Bogtan-Lagam Karnali and one in Middle Karnali exceeded the health standard for nitrate-N. The phosphate levels were high during the pre-monsoon season in Jhimruk and Rangun watershed in all the studied sites. Dissolved oxygen levels were relatively high during post-monsoon season. Results of the water quality index in all the studied sites revealed that the water quality ranges from being poor to good conditions in the spring sources. The results from this study suggested that the water bodies are relatively good and can be used for domestic purposes after suitable treatment.
\end{abstract}

\section{Keywords}

Springs, Water Quality Parameters, Drinking Sources, Nitrate Pollution, Monsoon Season

\section{Introduction}

Clean and safe drinking water is vital for human health and is a vital natural re- 
source fundamental to life and, as such, an integral part of our environment and climate system (BMZ, 2018; Deshwal, Saharan, \& Deshwal, 2016; Upreti, 2006). Nevertheless, unreliable and inadequate water supply is still one of the major challenges in developing countries as approximately 1.8 billion people drink water that is not safe (Sorlini, Palazzini, Sieliechi, \& Ngassoum, 2013; UN, 2018). Due to lack of clean and sufficient water developing countries are facing enormous health burden, such as diarrheal disease and dysentery (Deshwal et al., 2016; Edokpayi, Odiyo, Popoola, \& Msagati, 2018). For example, in India, waterborne diseases cost economic burden of USD 600 million each year (Deshwal et al., 2016). This scenario is most common in developing countries, especially in south East Asian countries and African countries (Hutton \& Chase, 2016).

Freshwater resources are reducing steadily with the growing population (Bruch et al., 2011). The increasing pace of urbanization, particularly in developing countries continues to affect the quality and quantity of freshwater detrimentally (Bruch et al., 2011). Already, many developing countries have been facing acute scarcity of water and have become water-stressed countries (Karn \& Harada, 2001; Kivaisi, 2001). In many developing countries like Nepal, Cambodia, Bangladesh, etc., sewage wastewaters, industrial effluents and municipal wastewaters are discharged directly into the aquatic environments, and such indiscriminate discharge of polluted effluents further intensifies the shortage of water supply by deteriorating the quality of available freshwater resources (Dallas, B., \& Ho, 2004; Karn \& Harada, 2001; Poudel \& Duex, 2017). Inadequate water supply is the key issue in the 21 st century. The water scarcity problem is exacerbated in rural areas, and it is estimated that still $11 \%$ of the world total population have no access to safe water, $84 \%$ of whom live in rural areas (Hutton \& Chase, 2016; Sorlini et al., 2013; UN, 2018; WHO, 2018). Inadequate supply of clean and safe drinking water can contribute to the underage death of children in rural areas of developing countries (Deshwal et al., 2016; Ding et al., 2017). Due to rapid urbanization and lack of adequate sanitation, pollution of surface waters in developing countries remains a major challenge (Traichaiyaporn \& Chitmanat, 2008).

Nepal is one of the least developed countries with low per capita water availability (Sharma, 2011). Although Nepal is considered as a rich country in terms of water resources, it has been facing water scarcity problems from the long time ago. Still more than $70 \%$ of the total population live in rural areas, and do not have a proper drinking water supply system (CBS, 2012). Most of the rural villages do not have potable water supplies piped into their homes, and fulfil their water demand by collecting water from rivers, springs, community stand-pipes, and boreholes (Sharma et al., 2016). Springs are of great importance in rural areas since almost $80 \%$ of the 13 million people in hill and mountain rely on it for fulfilling their primary water demand (CBS, 2012; Sharma et al., 2016; Tambe et al., 2012). Water collected from springs is stored in various containers that include buckets, drums, basins and local pots. However, there is possibility of contamination during collection and storage of water from spring sources (Gar- 
cia-Betancourt, Higuera-Mendieta, Cortes, \& Quintero, 2015).

Nepal faces a plethora of problems related to waterborne illnesses caused by pathogenic micro-organisms transmitted through water (Warner, Levy, Harpp, \& Farruggia, 2008). Lack of clean and safe drinking water increases the risk of diarrheal diseases, cholera, typhoid, dysentery and other waterborne diseases in Nepal (Shrestha et al., 2017). Most rural villages in Nepal are experiencing serious water shortage which is another factor causing waterborne diseases. Due to lack of adequate water supply rural households are compelled to use untreated and unsafe water for drinking and cooking purposes. Only limited percentage of the rural population have access to basic sanitation, and hence, rural population faces a high number of waterborne illnesses in Nepal (Shrestha et al., 2017). According to the Department of Health Service in Nepal, each year 3500 children die due to waterborne diseases (Aryal et al., 2012).

Therefore, provision of clean and reliable waters supply is crucial for better health and increased individual productivity (Haylamicheal \& Moges, 2012). Spring water quality and its appropriateness for use can be determined by assessing its physical and chemical features. For example, drinking water can be quantified using physicochemical parameters such as $\mathrm{pH}$, conductivity, turbidity, temperature, dissolved oxygen (DO), nitrate, nitrite, phosphate, ammonium, iron, arsenic, calcium, hardness, chloride, fluoride and magnesium. The concentration of these parameters varies widely according to different types of pollution, seasonal changes, and other changes in the spring surrounding (Yousefi \& Sahebian, 2017). Therefore, it is necessary to monitor spring water sources from time to time in order to check pollution as factors such as weather, climate, terrain, and the physical conditions of land and water resources play a vital role in the formation and establishment of settlements in rural areas. However, systematic studies on the assessment of drinking water supply and water quality has been lacking in Nepal.

The objective of this paper is to quantify the physicochemical features of spring water in western part of Nepal. The current study evaluated the quality of spring water in rural watershed of western Nepal by measuring physicochemical parameters and comparing them with the standards of Nepal Drinking Water Quality and the World Health Organization (WHO).

\section{Materials and Methods}

\subsection{Sampling and Data Collection}

The study was conducted in the five rural watersheds of western Nepal, namely: Jhimruk, Rangun, Thuligad, Bogatan-Lagam (Seti) and Middle Karnali watersheds (Figure 1). These watersheds are characterized by hills, mountains and plains, and the elevation of the watersheds extends from $300 \mathrm{~m}$ to $3000 \mathrm{~m}$ above sea level.

This research evaluated the physicochemical parameters of spring sources from the selected watersheds of Western Nepal during the year 2018. The samples 


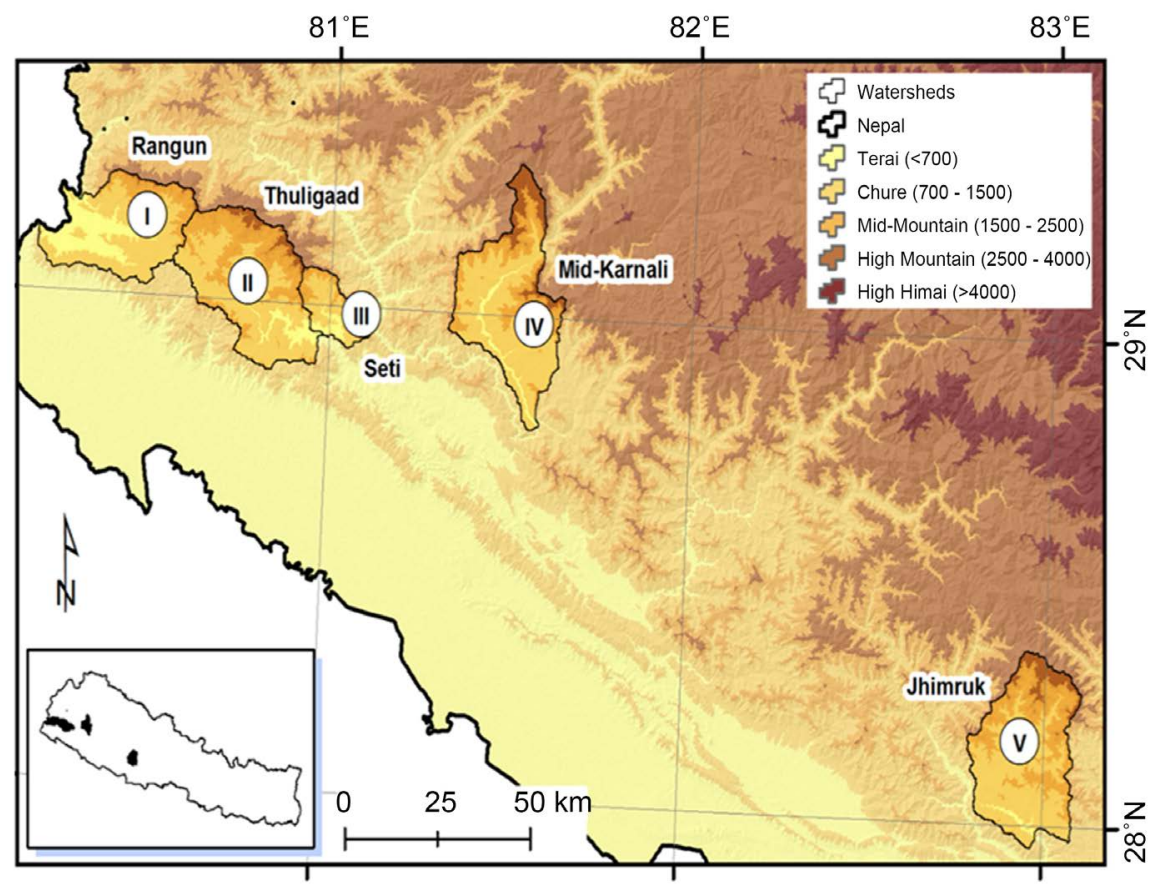

Figure 1. Selected watersheds for the study.

were collected during two seasons: pre-monsoon and post-monsoon, and tested for physicochemical qualities. The important water quality parameters, such as Conductivity, Turbidity, nitrate, nitrite, ammonia, $\mathrm{pH}$, phosphate, iron, temperature and dissolved oxygen were analyzed and compared with the WHO standard guideline.

A total of 155 water samples from different water sources were randomly collected. Water sample was collected based on the criteria, such as settlement, geographical setting, aspect (north-south facing), and land use pattern/agricultural/forest areas. The largest number of (48) samples were taken from the Bogatan-Lagam Karnali watershed. However the measured parameters did not vary significantly and thus, minimum of 20 samples were taken in remaining watersheds. Water samples for analysis of turbidity, conductivity, nitrate, nitrite, ammonia, iron and phosphate were taken using capped plastic tube $(100 \mathrm{~mL})$. Since most of the water sources were shallow, samples were taken manually from the shallow spots in the source by simply immersing the tube in the water.

\subsection{Sample Analyses}

All samples were analyzed according to the Standard Methods for the Examination of Water and Wastewater (APHA, 1998). Turbidity was measured directly in the field by the HACH Portable Turbidimeter (2100Q). Temperature and dissolved oxygen were also measured directly in the field by the HACH Portable Dissolved Oxygen Meter with Optical Sensor (HQ30D). Physicochemical parameters of source water samples were measured by a Hanna Multiparameter Waterproof Meter (HI9829) for $\mathrm{pH}$, nitrate, ammonia, turbidity, dissolved oxygen 
and conductivity. Prior to measurement, all the instruments were calibrated according to the manufacturer's instruction. Additionally, water samples were also analyzed onsite for selected water quality parameters using a complete set of water quality analysis kit: Akvo Caddisfly. $\mathrm{pH}$, nitrate, nitrite, iron, phosphate, ammonia and conductivity were measured using the Akvo Caddisfly app. The smartphone camera is used as a colorimeter sensor using the flash to illuminate the sample, and the app analyzes the water sample photograph against a calibrated range giving an accurate and reliable result after one minute. Strip tests are narrow plastic strips with active patches that change color when a certain substance is present in a water sample.

\subsection{Statistical Analyses}

Statistical analyses were performed using Excel software (MS 2019). Geographical Information System (GIS) is used to plot the study site and the Water Quality Index map.

\subsection{Water Quality Index}

In this study, the water quality index (WQI) has been calculated by using the standards of drinking water quality recommended by the World Health Organization (WHO) and Nepal Drinking Water Guideline. The weighted arithmetic index method developed by someone else (Brown, Cleiland, Deiniger, \& O'Connor, 1972) has been used for the calculation of WQI of the waterbody. Further, quality rating or sub index $\left(q_{n}\right)$ was calculated using the following expression.

$$
q_{n}=100\left[V_{n}-V_{i o}\right] /\left[S_{n}-V_{i o}\right]
$$

Let there be $n$ water quality parameters and quality rating or subindex $\left(q_{n}\right)$ corresponding to $n^{\text {th }}$ parameter is a number reflecting relative value of this parameter in the polluted water with respect to its standard permissible value.

$q_{n}=$ Quality rating for the nth water quality parameter;

$V_{n}=$ Estimated value of the nth parameter at a given sampling station;

$S_{n}=$ Standard permissible value of the nth parameter;

$V_{i o}=$ Ideal value of $\mathrm{n}^{\text {th }}$ parameter in pure water (i.e. 0 for all other parameters except the parameter $\mathrm{pH}$ and Dissolved oxygen (7.0 and $14.6 \mathrm{mg} / \mathrm{L}$ respectively)).

Unit weight was calculated by a value inversely proportional to the recommended standard value $S_{n}$ of the corresponding parameter.

$$
W_{n}=K / S_{n}
$$

$W_{n}=$ Unit weight for the nth parameters;

$S_{n}=$ Standard value for nth parameters;

$K=$ Constant for proportionality.

The overall WQI was calculated by aggregating the quality rating with the unit weight linearly.

$$
\mathrm{WQI}=\sum q_{n} W_{n} / \sum W_{n}
$$


Water quality index of the present waterbody is established from important various physiochemical parameters in pre-monsoon and post-monsoon seasons. WQI has a scale from 0 to 100 for qualifying the water quality, and in this study it is assumed that 51 to 75 good, 76 to 100 fair and $>100$ poor.

\section{Results and Discussion}

Water samples collected from the five respective watersheds during two seasons: pre-monsoon and post-monsoon were tested for physical qualities and chemical contents. The important water quality parameters, such as $\mathrm{pH}$, nitrate, temperature, nitrite, ammonia, phosphate, dissolved oxygen, conductivity, iron and turbidity were analyzed. These parameters can dictate the potability and appearance of the water from spring sources. All the results are compared with standard permissible limit recommended by the Nepal Drinking Water Guideline and WHO.

\subsection{Physical Water Quality Parameters}

The results of physical water quality parameters analyzed in the current study are indicated in Table 1. The turbidity data showed an irregular trend with most turbidity data being below $5 \mathrm{NTU}$ in both pre-monsoon and post-monsoon. In the Bogatan-Lagam Karnali watershed, the average turbidity was $7.7 \pm 12$ NTU during the pre-monsoon season which exceeded the standard guideline value set by WHO and Nepal drinking water quality. The highest value of turbidity 63.8 NTU (during pre-monsoon season) was observed in the Bogatan-Lagam. Dug wells had slightly higher turbidity values as compared to other spring sources.

Generally, turbidity is caused by variety of suspended particles that interfere with passage of light. The higher turbidity value in the dug well may be possibly due to presence of suspended sediment and organic matter/particles that enter from the agricultural field as the water source lies in the middle of the agricultural field. Moderately low levels of turbidity may not pose serious threat to the aquatic organisms as well as human. However, turbid or higher levels of turbidity water can carry pathogens, pollutants and nutrients, and thus indirectly constitute

Table 1. Mean values of physical water quality showing seasonal variation.

\begin{tabular}{|c|c|c|c|c|}
\hline \multirow{2}{*}{$\begin{array}{c}\text { Watersheds } \\
\text { Season }\end{array}$} & \multicolumn{2}{|c|}{ Turbidity } & \multicolumn{2}{|c|}{ Temperature } \\
\hline & Pre-Monsoon & Post-Monsoon & Pre-Monsoon & Post-Monsoon \\
\hline Middle Karnali & $3.8 \pm 3.1$ & $2.85 \pm 1.69$ & $24.7 \pm 3.6$ & $18.48 \pm 1.80$ \\
\hline Rangun & $4.6 \pm 5.8$ & $2.59 \pm 2.5$ & $24.7 \pm 3.4$ & $17.10 \pm 1.85$ \\
\hline Thuligad & $3.5 \pm 2.0$ & $4.11 \pm 5.28$ & $24.4 \pm 1.9$ & $19.60 \pm 1.29$ \\
\hline Bogatan-Lagam & $7.7 \pm 12$ & $2.53 \pm 4.78$ & $22.9 \pm 2.7$ & $18.02 \pm 2.10$ \\
\hline Jhimruk & $3.2 \pm 3.5$ & $1.73 \pm 1.00$ & $23.4 \pm 2.1$ & $17.00 \pm 1.89$ \\
\hline
\end{tabular}


a health issue (WHO, 2012). Nevertheless, turbidity in water is more of an aesthetic contaminant rather than a health problem. In the present study, majority of the water sources are primarily used for drinking and cooking purpose, and thus pose less threat to human health although high concentrations of particulate matter can cause increased sedimentation and siltation in a water source, which in turn can ruin habitat areas for fish and other aquatic life.

Temperature varied from $17.5^{\circ} \mathrm{C}$ to $32.3^{\circ} \mathrm{C}$ in pre-monsoon season whereas the range is from $11.50^{\circ} \mathrm{C}$ to $23.2^{\circ} \mathrm{C}$ in the post-monsoon season. Comparative average seasonal variation is shown in Table 1 above. The higher temperature in the water sources suggests that it has fewer amounts of insoluble pollutants. Temperature is one of the important parameters of water that affects the amount of dissolved oxygen in the water. The solubility of oxygen decreases as water temperature increases. Cold water can hold more amount of oxygen than that of warm water. For example, water at $0^{\circ} \mathrm{C}$ will hold up to $14.6 \mathrm{mg} / \mathrm{L}$ oxygen, while at $30^{\circ} \mathrm{C}$ it will hold only up to $7.6 \mathrm{mg} / \mathrm{L}$ oxygen (McCaffrey, 2018). It also affects photosynthetic activity, diffusion rate or gases, the metabolic rate of aquatic animals, mobility, migration patterns, and the sensitivity of organisms to toxins, parasites and diseases (Kale, 2016; McCaffrey, 2018).

\subsection{Chemical Water Quality Parameters}

The majority of the sampled water sources had a $\mathrm{pH}$ slightly lower than the neutrality in post-monsoon season. We observed that the average $\mathrm{pH}$ values in Thuligad, Rangun and Middle Karnali had closer to 6.5 in both the seasons. No significant variation in two seasons was observed. The minimum $\mathrm{pH}$ of 5.0 was observed in Middle Karnali in pre-season monsoon. Although $\mathrm{pH}$ is a major water quality parameter, there is no health-based guideline for $\mathrm{pH}$. Nevertheless, the WHO has suggested that the drinking water should have $\mathrm{pH}$ in the range of 6.5 8.5. Fortunately, in all watersheds, the average $\mathrm{pH}$ value was within the standard guideline values set up by Nepal Drinking Water Quality and WHO. Table 2 shows the variation in $\mathrm{pH}$ during pre-monsoon and post-monsoon seasons in selected watersheds.

In general, a shift of $\mathrm{pH}$ in either direction from neutral may indicate presence of a pollutant in the spring sources (Cirino, 2018). However, some springs are naturally acidic or basic, and thus, $\mathrm{pH}$ may not necessarily indicate pollution.

Table 2. Mean values of physical water quality showing seasonal variation.

\begin{tabular}{ccc}
\hline Watershed & Pre-Monsoon & Post-Monsoon \\
\hline Bogatan-Lagam & $8.1 \pm 0.5$ & $7.22 \pm 0.58$ \\
Middle Karnali & $6.7 \pm 0.6$ & $6.4 \pm 0.35$ \\
Rangun & $6.8 \pm 0.6$ & $6.75 \pm 0.62$ \\
Thuligad & $6.8 \pm 0.7$ & $6.57 \pm 0.53$ \\
Jhimruk & $7.8 \pm 0.4$ & $7.77 \pm 0.62$
\end{tabular}


Generally, the $\mathrm{pH}$ of clean water depends on several factors, including the geology and vegetation within the watersheds (Mesner \& Geiger, 2005). The low pH in the related watersheds could be due to the presence of humic acids produced by decaying vegetation in the soil as most of the spring sources are covered by forest. The low $\mathrm{pH}$ values in the selected watersheds could be due to presence of pine forests as the decomposing needles of these trees add to the acidity of soils and also influence the acidity of the nearby springs (Mesner \& Geiger, 2005). pH determines water reactivity capacity, and at low $\mathrm{pH}$ heavy metals such as cadmium, lead and chromium dissolve more easily and pose serious threat to aquatic organisms (Mesner \& Geiger, 2005).

During the pre-monsoon season, the minimum and maximum electrical conductivity values $26 \mu \mathrm{S} / \mathrm{Cm}$ and $\mu \mathrm{S} / \mathrm{Cm} 1283$ were observed respectively in the Middle Karnali and Jhimruk watersheds. In all selected watersheds, conductivity values were relatively higher although the observed values were within the limit of the guideline value given by WHO for drinking water. Conductivity is the measure of capacity of a substance to conduct the electric current where dissolved ions are the conductors, and the major positively charged ions, including sodium $\left(\mathrm{Na}^{+}\right)$, calcium $\left(\mathrm{Ca}^{+2}\right)$, potassium $\left(\mathrm{K}^{+}\right)$and magnesium $\left(\mathrm{Mg}^{+2}\right)$ contribute in the conductivity of water (Deshwal et al., 2016). Although these ions were not measured it is anticipated that the high conductivity could be due to presence of a higher amount of $\mathrm{Ca}^{+2}$ and $\mathrm{Mg}^{+2}$. Table 3 shows the seasonal variation of conductivity and dissolved oxygen in the selected watersheds.

The mean concentrations of dissolved oxygen measured during the pre-monsoon period in selected watersheds ranged from 5.7 to $6.1 \mathrm{mg} / \mathrm{L}$. The highest level of dissolved oxygen $(10.1 \mathrm{mg} / \mathrm{L})$ was observed in the Bogatan-Lagam watershed, whereas the lowest level of dissolved oxygen $(1.5 \mathrm{mg} / \mathrm{L})$ was observed in the Rangun watershed. The dissolved oxygen value of water sample measured during the post-monsoon period was higher than those sampled during the pre-monsoon period. The variation of dissolved oxygen in the two-season period is shown in Table 2. Ideally rapidly moving water, such as in a mountain stream or large river, tends to contain a high level of dissolved oxygen, whereas stagnant or still water contains less.

Mean nitrate concentration in springs ranged from 3.19 to $9.72 \mathrm{mg} / \mathrm{L}$ in

Table 3. Mean values of conductivity and dissolved oxygen in two seasons.

\begin{tabular}{|c|c|c|c|c|}
\hline \multirow{2}{*}{$\begin{array}{c}\text { Watersheds } \\
\text { Season }\end{array}$} & \multicolumn{2}{|c|}{ Electrical Conductivity } & \multicolumn{2}{|c|}{ Dissolved Oxygen } \\
\hline & Pre-Monsoon & Post-Monsoon & Pre-Monsoon & Post-Monsoon \\
\hline Middle Karnali & $172 \pm 140$ & $14.3 \pm 119$ & $6.1 \pm 0.6$ & $8.01 \pm 0.65$ \\
\hline Rangun & $194 \pm 196$ & $70.57 \pm 56$ & $5.7 \pm 1.3$ & $7.49 \pm 0.77$ \\
\hline Thuligad & $188 \pm 203$ & $72 \pm 111$ & $5.7 \pm 0.6$ & $6.85 \pm 0.64$ \\
\hline Bogatan-Lagam & $216 \pm 143$ & $255 \pm 170$ & $6.0 \pm 1.6$ & $8.01 \pm 0.65$ \\
\hline Jhimruk & $518 \pm 366$ & $1.73 \pm 1.00$ & $5.9 \pm 0.7$ & $8.37 \pm 0.75$ \\
\hline
\end{tabular}


pre-monsoon and 1.27 to $3.70 \mathrm{mg} / \mathrm{L}$ in post-monsoon. Nitrate values are commonly reported as either nitrate or as nitrate-nitrogen, and in this study the nitrate value is reported as nitrate ion. The maximum contaminant level as $\mathrm{NO}_{3}-\mathrm{N}$ is $10 \mathrm{mg} / \mathrm{L}$. The maximum contaminant level is the highest level of nitrate that is allowable in public drinking water. In the current study, the maximum nitrate value of $44 \mathrm{mg} / \mathrm{L}$ was observed in the Middle Karnali watershed in pre-monsoon season. The variation of nitrate value in both seasons is presented in Table 4. Relatively higher concentration of nitrate value was observed during pre-monsoon as compared to the water sources sampled during post-monsoon. Majority of the spring sources are in the vicinity of the settlement and agricultural land. The presence of high level of nitrate $(44 \mathrm{mg} / \mathrm{L})$ in the observed water sources might be due to non-point sources.

Nitrite is another nitrogenous compound, which is an intermediate product of the transformation of ammonia into nitrate by nitrosomonas bacteria. It is the ionized form of nitrous acid $\left(\mathrm{HNO}_{2}\right)$, and is very toxic life ammonia (Halim et al., 2018). Nitrites ate detected in all sources. The mean variation is in the range 0.003 to $0.01 \mathrm{mg} / \mathrm{L}$ during pre-monsoon. The maximum value of nitrite 0.75 $\mathrm{mg} / \mathrm{L}$ was observed in Middle Karnali watershed in post-monsoon season. Nitrites might be presence in the spring sources as a result of either the processes of nitrification, though ammonium ion is converted to nitrite ion or as a reduction of nitrite ions or anaerobic fecal pollution (Mihale, 2015). Since nitrite is readily oxidized to nitrite, little nitrite is present in oxygenated spring water sources. High concentration of nitrogenous pollutants in water can cause methemoglobinemia or blue baby syndrome, a condition found especially in infant less than six months. The differing forms of nitrogen are relatively stable in most water with ammonia transferring into nitrite that slowly transforming in well oxygenated water system (Hasan, Rajia, Kabir, \& Latifa, 2009).

In this study, the phosphate was absent in many sampling spring sources. However, in some sampling points, the observed phosphate values were slightly higher. The average concentration of phosphate measured in spring sources ranged from 0.60 to $8.81 \mathrm{mg} / \mathrm{L}$ in ore-monsoon season. The maximum value of $35 \mathrm{mg} / \mathrm{L}$ was observed at Middle Karnali during the pre-monsoon period. The high concentrations of phosphate may be due to agricultural runoff or washing neighboring farmland which used fertilizers based in phosphate. Table 5 displays

Table 4. Mean values of nitrate and nitrite during pre-monsoon and post-monsoon.

\begin{tabular}{ccccc}
\hline Watersheds & \multicolumn{2}{c}{ Nitrate } & \multicolumn{2}{c}{ Nitrite } \\
\hline Season & Pre-Monsoon & Post-Monsoon & Pre-monsoon & Post-Monsoon \\
\hline Middle Karnali & $7.45 \pm 0.13$ & $2.64 \pm 4.03$ & $0.03 \pm 0.01$ & $0.15 \pm 0.20$ \\
Rangun & $9.58 \pm 11.36$ & $2.17 \pm 1.27$ & $0.003 \pm 0.01$ & $0.17 \pm 0.17$ \\
Thuligad & $9.72 \pm 11.94$ & $1.27 \pm 0.98$ & $0.001 \pm 0.01$ & $0.11 \pm 0.13$ \\
Bogatan-Lagam & $3.19 \pm 4.97$ & $3.70 \pm 7.25$ & $0.01 \pm 0.01$ & $0.06 \pm 0.12$ \\
Jhimruk & $3.50 \pm 4.05$ & $2.98 \pm 2.31$ & $0.01 \pm 0.02$ & $0.04 \pm 0.05$ \\
\hline
\end{tabular}


Table 5. Mean values of phosphate during pre-monsoon and post-monsoon.

\begin{tabular}{ccc}
\hline Watershed & Pre-Monsoon & Post-Monsoon \\
\hline Bogatan-Lagam & $1.82 \pm 1.12$ & $0.76 \pm 0.12$ \\
Jhimruk & $6.65 \pm 3.12$ & $1.1 \pm 0.56$ \\
Thuligad & $3.98 \pm 2.22$ & $2.47 \pm 0.78$ \\
Rangun & $8.81 \pm 3.24$ & $4.17 \pm 1.12$ \\
Middle Karnali & $0.6 \pm 0.2$ & $1.63 \pm 0.46$ \\
\hline
\end{tabular}

the variation of phosphate during two seasons. The phosphate concentration was slightly lower in all the sampled water sources during post-monsoon season as compared to pre-monsoon. The average concentration of phosphate during post-monsoon ranged from $0.76 \mathrm{mg} / \mathrm{L}$ to $4.17 \mathrm{mg} / \mathrm{L}$.

Iron was observed only in Bogatan-Lagam Karnali and Rangun watersheds during pre-monsoon season. The average iron concentration ranged from 0.01 to $0.05 \mathrm{mg} / \mathrm{L}$. the highest values of $0.60 \mathrm{mg} / \mathrm{L}$ and $0.40 \mathrm{mg} / \mathrm{L}$ were observed in the Bogatan-Lagam and Rangun, respectively. In both the watersheds, the highest values exceeded the WHO standard value. Although no health-based standard value is proposed or set for iron, water taste is affected above $300 \mu \mathrm{mg} / \mathrm{L}$ (WHO, 2012). Table 6 shows the concentrations of iron in the studied sites.

There was no significant variation in the ammonia concentration during the two seasons: pre-monsoon and post-monsoon. Ammonia was not observed in most of the sampled water sources. However, determined ammonia concentrations were fairly higher as compared to the guidelines values given by WHO and Nepal Drinking Water Quality. The mean concentration of ammonia was in the range of 0.51 to $1.31 \mathrm{mg} / \mathrm{L}$ during pre-monsoon. While the mean concentration of ammonia during post-monsoon was in the range of 0 to $1.34 \mathrm{mg} / \mathrm{L}$. Naturally ammonium ion occurs in water bodies arising from the microbiological decomposition of nitrogenous compounds in organic matter or as a result of reduced nitrite ions. Ammonia may also be discharged directly into water bodies by some industrial processes or as a component of domestic sewage or animal slurry. There were no industries in the studied region, and thus the livestock may impact the ammonia concentration. In rural livelihood, majority of the households keep livestock for different purposes. Some household has started goat farming as well, and they graze around the water sources. During post-monsoon season, ammonium ion was not detected in water samples taken from Thuligad watershed.

Generally, aquatic environment contains low levels of ammonia due to the nitrification process by Nitrosomonas species to form nitrite and then by Nitrobacter species that convert the nitrite to nitrate (Berkowitz, Dror, \& Yaron, 2008). Rivers exhibit ammonia level of less than $6 \mathrm{mg} / \mathrm{L}$ (Mihale, 2015). However, the ammonia level can be very low under favorable conditions, including good amount of oxygen, favorable $\mathrm{pH}$ and temperature, and microbial population 
Table 6. Mean values of iron during pre-monsoon and post-monsoon.

\begin{tabular}{ccc}
\hline Watershed & Pre-Monsoon & Post-Monsoon \\
\hline Bogatan-Lagam & $0.01 \pm 0.02$ & $0.01 \pm 0.09$ \\
Jhimruk & 0 & $0.01 \pm 0.001$ \\
Thuligad & 0 & 0 \\
Rangun & $0.05 \pm 0.001$ & 0 \\
Middle Karnali & 0 & 0 \\
\hline
\end{tabular}

(Berkowitz et al. 2008). During post-monsoon season, the ammonia was not determined most of the sampled water sources. This is probably due to the favorable conditions for microbial growth in the area, and presence of good amount of oxygen in the water sources. Nevertheless, the ammonia level higher than 1 $\mathrm{mg} / \mathrm{L}$ observed in few water sources is indicative of suspicious recent pollution from surrounding areas (Table 7).

\subsection{Water Quality Index}

WPI of the present spring sources is established from important various physicochemical parameters analyzed during pre-monsoon and post-monsoon. Examples of values of seasonal WQI based on ten physiochemical parameters were shown for Karnali Watershed in Figure 2. Results showed that in pre-monsoon season, 20 sampling points had good, 4 had fair and 3 had poor condition in Middle Karnali watershed. The WQI obtained for the poor site were 131, 100.32 and 100.96, respectively. However, in post-monsoon all the sampling sites had a good condition. This water quality rating indicates that, the status of the waterbody is relatively good and it is suitable for the human uses. However, the poor water quality rating in pre-monsoon season clearly shows that proper attention is required to prevent spring sources from anthropogenic activities that deteriorate the water quality.

In remaining watersheds, the water quality rating was obtained better in post-monsoon season as compared to pre-monsoon. The main season for this might be due to the improvement in the turbidity and dissolved oxygen data. The turbidity values obtained in post-monsoon samples taken in spring sources were minimal and within the guideline values given by the WHO. In Thuligad, 13 samples had good WQI in pre-monsoon and 15 samples had good WQI in post-monsoon season. In Rangun, 4 samples had poor water quality with the WQI values of $178.79,116.68,101.54$ and 108 , respectively in pre-monsoon season. In post-monsoon, all samples had good water quality.

In Jhimruk and Bogtan-Lagam Karnali, the measured samples had relatively good water quality. In Jhimruk watershed none of the samples had poor water quality in both seasons. However, in Bogtan-Lagam Karnali one sample had poor water quality in pre-monsoon and 2 samples had poor water quality in post-monsoon season. 
Table 7. Mean values of ammonium during pre-monsoon and post-monsoon.

\begin{tabular}{ccc}
\hline Watershed & Pre-Monsoon & Post-Monsoon \\
\hline Bogatan-Lagam & $0.51 \pm 0.46$ & $1.34 \pm 0.51$ \\
Jhimruk & $0.98 \pm 0.34$ & $1.05 \pm 0.62$ \\
Thuligad & $1.31 \pm 0.46$ & 0 \\
Rangun & $0.97 \pm 0.44$ & $0.14 \pm 0.01$ \\
Middle Karnali & $1.06 \pm 0.52$ & $0.32 \pm 0.02$ \\
\hline
\end{tabular}

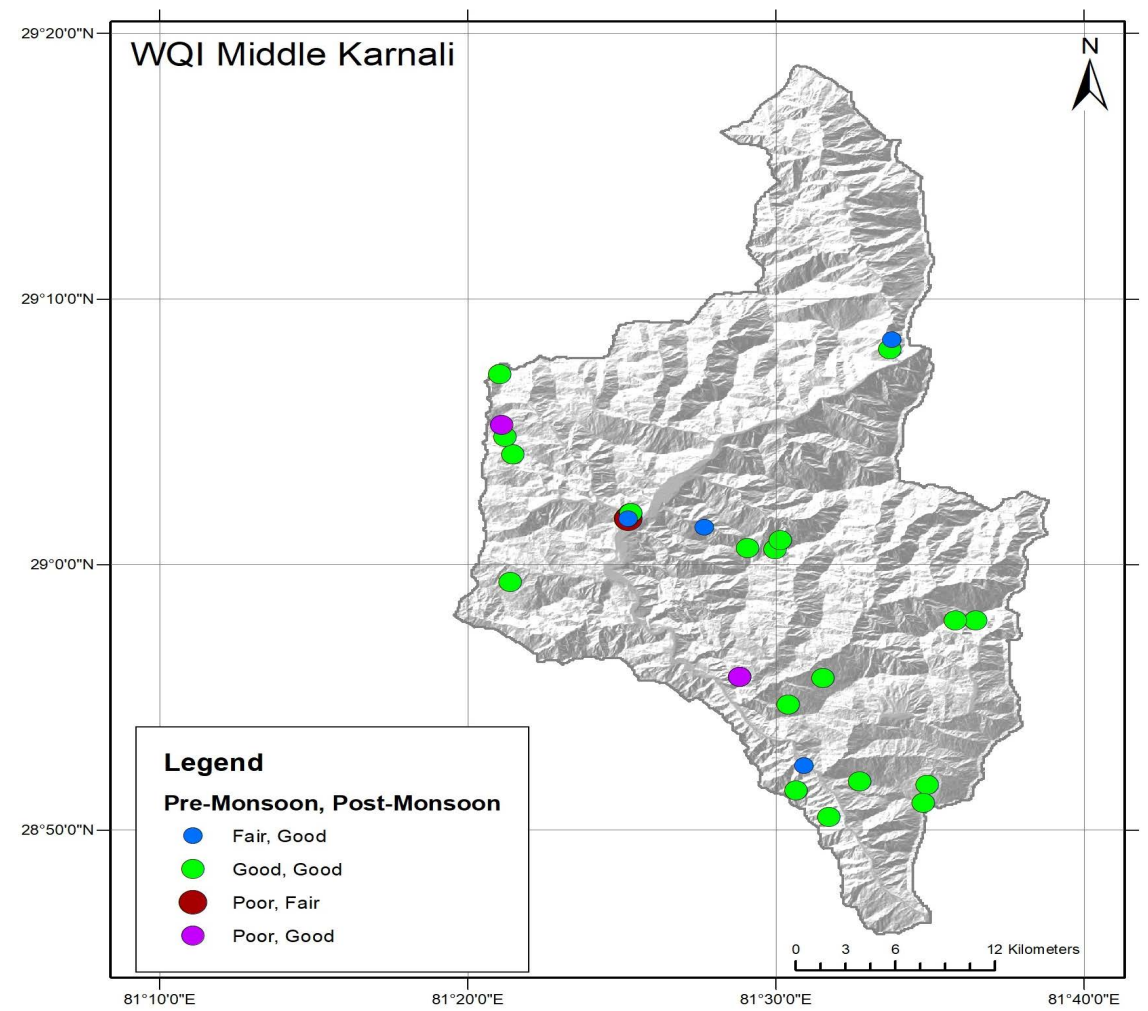

Figure 2. Water quality index value during pre-monsoon and post-monsoon in Karnali watershed.

\section{Conclusion}

This article describes a survey carried out during pre-monsoon and post-monsoon periods in rural watersheds of Western Nepal to assess the physical-chemical quality of spring water sources used by village people for domestic and drinking purposes. Till date, water quality in this region is not analyzed, and thus, this research provided baseline water quality data in this region. Additionally, it contributed to identifying the main concerns regarding the quality of drinking water, in order to suggest appropriate solutions to reduce the observed contaminations and to motivate the local public authorities to plan future interventions in this sector. Regarding physical-chemical parameters, majority of the sampled water sources had relatively good quality, with key exceptions related to occurrence of ammonia contamination. Although ammonia is not observed in all wa- 
ter sources, the determined value exceeded the guideline value set up by WHO. This identified that ammonia concern is significant and an immediate intervention is required to prevent widespread and long-term exposure. Phosphate value is observed slightly higher in all sampled water sources and should be taken into consideration for preventing eutrophication and occurrence of other detrimental effects of it on water resources. Many people living in the rural areas of studied sites do not have access to treated potable water. The main source of water for rural population is mainly spring source and nearby river and creeks.

\section{Acknowledgements}

The authors would like to acknowledge the financial support of American People for this study through the United States Agency for International Development (USAID). The contents of this study are the sole responsibility of authors and do not necessarily reflect the views of USAID or the United States Government.

\section{Conflicts of Interest}

The authors declare no conflicts of interest regarding the publication of this paper.

\section{References}

APHA (1998). Standard Methods for the Examination of Water and Waste Water (20th ed.). Washington DC: American Public Health Association/American Water Works Association, Water Environment Federation.

Aryal, K. K., Joshi, H. D., Dhimal, M., Singh, S. P., Dhakal, P., Dhimal, B., \& Bhusal, C. L. (2012). Environmental Burden of Diarrhoeal Diseases Due to Unsafe Water Supply and Poor Sanitation Coverage in Nepal. Journal of Nepal Health Research Council, 10, 125-129.

Berkowitz, B., Dror, I., \& Yaron, B. (2008). Contaminant Geochemistry: Transport and Fate in the Subsurface Environment. Berlin: Springer-Verlag. https://doi.org/10.1007/978-3-540-74382-8

BMZ (2018). BMZ Strategy for Interlinkages between Water, the Environment and Climate Change: Synergies and Conflicts between Goals. Bonn: Federal Ministry for Economic Cooperation and Development (BMZ), Division for Water, Urban Development Mobility.

Brown, R. M., Cleiland, N. J. M., Deiniger, R. A., \& O’Connor, M. F. A. (1972). Water Quality Index-Crossing the Physical Barrier. In S. H. Jenkins (Ed.), Proceedings in International Conference on Water pollution Research (Vol. 6, pp. 787-797). Jerusalem: Elsevier.

Bruch, I., Fritsche, J., Banninger, D., Alewell, U., Sendelov, M., Hurlimann, H., C., A. et al. (2011). Improving the Treatment Efficiency of Constructed Wetlands with Zeolite-Containing Filter Sands. Bioresource Technology, 102, 937-941. https://doi.org/10.1016/j.biortech.2010.09.041

CBS (2012). National Population and Housing Census 2011 (National Report). Kathmandu: National Planning Commission Secretariat, Central Bureau of Statistics, Government of Nepal. 
Cirino, E. (2018). What pH Should May Drinking Water Be? Healthline Newsletter.

Dallas, S., B., S., \& Ho, G. (2004). Reedbeds for Greywater Treatment-Case Study in Santa-Monteverde, Costa Rica, Central America. Ecological Engineering, 23, 55-61. https://doi.org/10.1016/j.ecoleng.2004.07.002

Deshwal, J. P., Saharan, J. P., \& Deshwal, B. R. (2016). A Study on Water Quality Parameters of Drinking Water of Rural Areas of Narwana, Haryana (India). International Journal of Current Research, 8, 39329-39333.

Ding, Z., Zhai, Y., Wu, C., Lu, Q., Lin, J., \& He, F. (2017). Infectious Diarrheal Disease Caused by Contaminated Well Water in Chinese Schools: A Systematic Review and Meta-Analysis. Journal of Epidemiology, 27, 274-281.

https://doi.org/10.1016/j.je.2016.07.006

Edokpayi, J. N., Odiyo, J. O., Popoola, E. O., \& Msagati, T. A. M. (2018). Evaluation of Microbiological and Physicochemical Parameters of Alternative Source of Drinking Water: A Case Study of Nzhelele River, South Africa. The Open Microbiology Journal, 12, 18-27. https://doi.org/10.2174/1874285801812010018

Garcia-Betancourt, T., Higuera-Mendieta, D. R., C., G.-U., Cortes, S., \& Quintero, J. (2015). Understanding Water Storage Practices of Urban Residents of an Endemic Dengue Area in Colombia: Perceptions, Rationale and Socio-Demographic Characteristics. PLoS ONE, 10, e0129054. https://doi.org/10.1371/journal.pone.0129054

Halim, M. A., Sharmin, S., Rahman, H. M. H., Haque, M. M., Rahman, M. S., \& Islam, M. S. (2018). Assessment of Water Quality Parameters in Baor Environment, Bangladesh: A Review. International Journal of Fisheries and Aquatic Studies, 6, 269-263.

Hasan, I., Rajia, S., Kabir, K. A., \& Latifa, G. A. (2009). Comparative Study on the Water Quality Parameters in Teo Rural and Urban Rivers Emphasizing on the Pollution Level. Global Journal of Environmental Research, 3, 218-222.

Haylamicheal, I. D., \& Moges, A. (2012). Assessing Water Quality of Rural Water Supply Schemes as a Measure of Service Delivery Sustainability: A Case Study of WondoGenet District, Southern Ethiopia. African Journal of Environmental Science and Technology, 6, 229-236. https://doi.org/10.5897/AJEST12.010

Hutton, G., \& Chase, C. (2016). The Knowledge Base for Achieving the Sustainable Development Goal Targets on Water Supply, Sanitation and Hygiene. International Journal of Environmental Research and Public Health, 13, 536-571. https://doi.org/10.3390/ijerph13060536

Kale, V. S. (2016). Consequences of Temperature, pH, Turbidity and Dissolved Oxygen Water Quality Parameters. IARJSET, 3, 186-190.

Karn, S. K., \& Harada, H. (2001). Surface Water Pollution in Three Urban Territories of Nepal, India and Bangladesh. Environmental Management, 28, 483-496. https://doi.org/10.1007/s002670010238

Kivaisi, A. K. (2001). The Potential for Constructed Wetlands for Wastewater Treatment and Reuse in Developing Countries: A Review. Ecological Engineering, 16, 545-560. https://doi.org/10.1016/S0925-8574(00)00113-0

McCaffrey, S. (2018). Water Quality Parameters and Indicators. Waterwatch, New South Wales.

Mesner, N., \& Geiger, J. (2005). pH: Understanding Your Watershed. Water Quality, Utah State University Extension.

Mihale, M. T. (2015). Nitrogen and Phosphorous Dynamics in the Waters of the Great Ruaha River, Tanzania. Journal of Water Resources and Ocean Science, 4, 59-71. https://doi.org/10.11648/j.wros.20150405.11 
Poudel, D. D., \& Duex, T. W. (2017). Vanishing Springs in Nepalese Mountains: Assessment of Water Sources, Farmers' Perceptions, and Climate Change Adaptation. Mountain Research and Development, 37, 35-46. https://doi.org/10.1659/MRD-JOURNAL-D-16-00039.1

Sharma, B., Nepal, S., Gyawali, D., Pokharel, G., Wahid, S., Mukherji, A., Shrestha, A. et al. (2016). Springs, Storage Towers, and Water Conservation in the Midhills of Nepal. ICIMOD Working Paper 2016/3, Kathmandu: International Center for Integrated Mountain Development.

Sharma, S. K. (2011). The Political Economy of Climate Change Governance in the Himalayan Region of Asia: A Case Study of Nepal. Social and Behavioral Sciences, 14, 129-140. https://doi.org/10.1016/j.sbspro.2011.03.030

Shrestha, A., Sharma, S., Gerold, J., Erismann, S., Sagar, S., Koju, R., Utzinger, J. et al. (2017). Water Quality, Sanitation, and Hygiene Conditions in Schools and Households in Dolakha and Ramechhap Districts, Nepal: Results from a Cross-Sectional Survey. International Journal of Environmental Research and Public Health, 14, pii: E89. https://doi.org/10.3390/ijerph14010089

Sorlini, S., Palazzini, D., Sieliechi, J. M., \& Ngassoum, M. B. (2013). Assessment of Physical-Chemical Drinking Water Quality in the Logone Valley (Chad-Cameroon). Sustainability, 5, 3060-3076. https://doi.org/10.3390/su5073060

Tambe, S., Kharel, G., Arrawatia, M. L., Kulkarni, H., Mahamuni, K., \& Ganeriwala, A. K. (2012). Reviving Dying Springs: Climate Change Adaptation Experiments from the Sikkim Himalaya. Mountain Research and Development, 32, 62-72. https://doi.org/10.1659/MRD-JOURNAL-D-11-00079.1

Traichaiyaporn, S., \& Chitmanat, C. (2008). Water Quality Monitoring in Upper Ping River, Thailand. Journal of Agriculture and Social Sciences, 4, 31-34.

UN (2018). Global Issues: Water. http://www.un.org/en/sections/issues-depth/water

Upreti, T. (2006). Prospects and Problems of Nepalese Water Resources: International Watercourses Law and Its Application in South Asia (pp. 181-256). Kathmandu: Pairavi Prakashan.

Warner, N. R., Levy, J., Harpp, K., \& Farruggia, F. (2008). Drinking Water Quality in Nepal's Kathmandu Valley: A Survey and Assessment of Selected Controlling Site Characteristics. Hydrogeology Journal, 16, 321-334.

https://doi.org/10.1007/s10040-007-0238-1

WHO (2012). Guidelines for Drinking-Water Quality (4th ed.). Geneva: World Health Organization.

WHO (2018). Drinking Water: Key Facts. Geneva: World Health Organization. http://www.who.int/news-room/fact-sheets/detail/drinking-water

Yousefi, Z., \& Sahebian, H. (2017). Assessment of Chemical Quality of Drinking Water in Rural Areas of Babol, Northern Iran. Environmental Health Engineering and Management Journal, 4, 233-237. https://doi.org/10.15171/EHEM.2017.32 